Vol. 40(1), pp. 16-27, June 2021

ISSN 1821-536X (print)

ISSN 2619-8789 (electronic)
Tanzania Journal of Engineering and Technology Copyright $\odot 2021$ College of Engineering and

Technology, University of Dar es Salaam

Full length Research Paper

\title{
Prediction of Uniaxial Compressive Strength of Granite Rock Samples of Lugoba Quarry Using Rebound Hammer Test
}

\author{
Moses Kongola $^{1^{*}}$ and Karim R. Baruti ${ }^{2}$ \\ ${ }^{1}$ Dar es Salaam Institute of Technology, Tanzania \\ ${ }^{2}$ Department of Chemical and Mining Engineering, University of Dar es Salaam, Tanzania \\ *Corresponding author: mkongola@gmail.com, mkongola@dit.ac.tz
}

\begin{abstract}
Rebound hammer test is widely used as an indirect measure of uniaxial compressive strength for engineering materials such as concrete, soil, and rock in both civil and mining engineering works. In quarries, uniaxial compressive strength is a crucial parameter in the analysis of geotechnical problems involving rock stability and rock blasting design. This study aims at establishing the empirical models of uniaxial compressive strength fits on rebound hammer number that can be used to predict uniaxial compressive strength of granitic rock at Lugoba Quarry. Data for direct uniaxial compressive strength were obtained from uniaxial compressive strength test carried out on 20 core samples at the Dar es Salaam Institute of Technology Geotechnical Laboratory using ISMR Standard Procedures. The rebound hammer test was carried out using testing hammer type $N$. The tests were done horizontally on two scanline's geotechnical domains of the rock mass on the footwall side of the quarry. The obtained results of UCS ranging from 105 to $132.5 \mathrm{MPa}$ and RHN from 44.90 to 49.5 were found to be comparable with values of other granitic rocks in other parts of the world. Regression Analysis using SPSS software was carried out to develop 5 regression models of UCS vs.RHN. The values of $R^{2}$ obtained in this study were found to be between 0.93 and 0.95 , which are comparable with other studies. This implies that RHN accounted between 93 and $95 \%$ of the total variation of the UCS and the relationships were very strong. Two models; Logarithmic and exponential were found to be appropriate and recommended for application at Lugoba Quarry.
\end{abstract}

Keywords: Uniaxial compressive strength, Rebound hammer number, Granitic rock, Regression model.

\section{INTRODUCTION}

Lugoba quarries located $120 \mathrm{~km}$ from Dar es Salaam (Figure 1) are the main sources of granite aggregates used in ordinary and strategic civil and road construction works in the city of Dar es Salaam (Twiga Cement Company, 2014). With a population of more than 6 million people, the annual growth rate of $5 \%$ and construction growth rate of $12 \%$ (United Nations, 2019; Kikwasi and Escalante, 2020), Dar es Salaam city is expected to consume more aggregates from Lugoba quarries due to its (Lugoba) proximity to the city and the quality of the granite. 
Uniaxial compressive strength is one of the key geotechnical parameters affecting the quality of both intact rock and rock mass characteristics for various intended uses such as rock fragmentation, excavation, construction and rock stability. Furthermore, design of rock fragmentation machinery, evaluation of excavatability, rippability and blastability of rock mass, selection of primary rock fragmentation methods and achieving rock stability for excavations requires Uniaxial Compressive Strength (UCS) as a primary input parameter (Bewick et al., 2015; Hack, 1998; Laubscher, 1990).

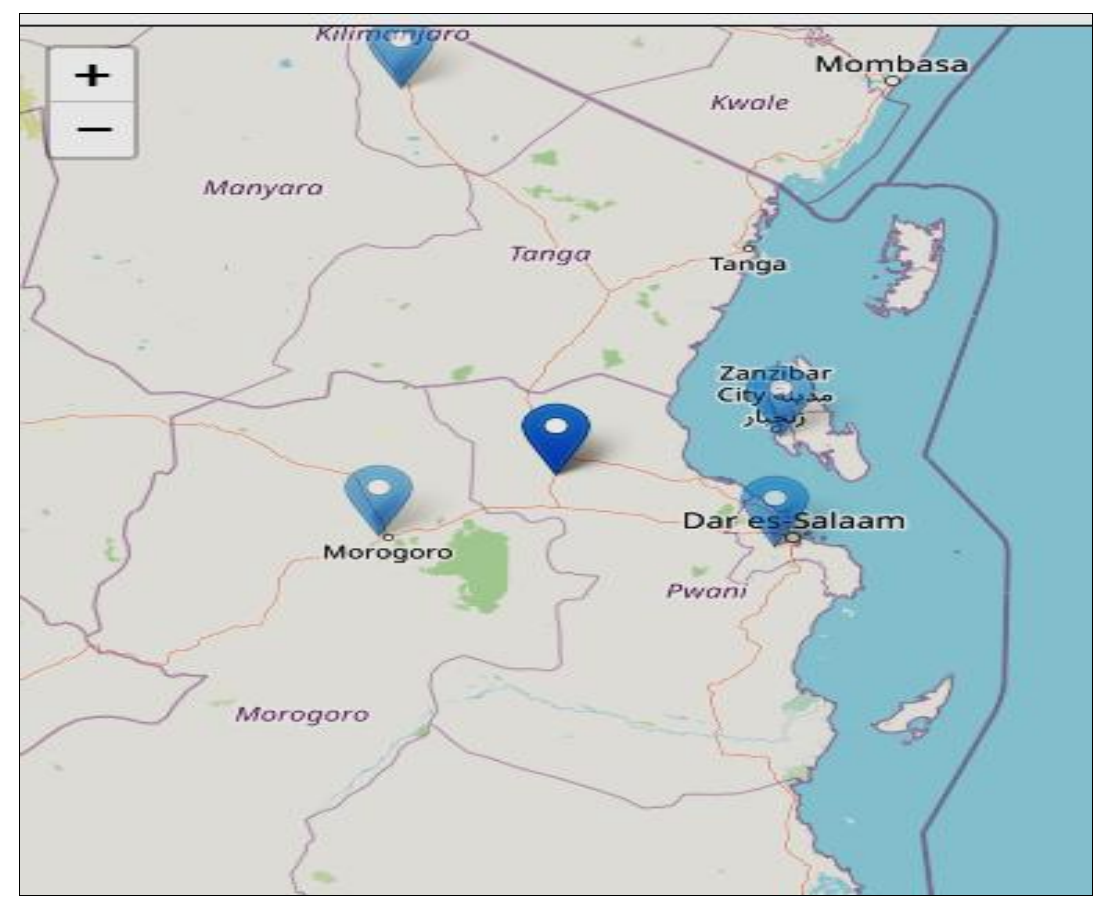

Figure 1: Location Map of Lugoba and Dar es Salaam

Both direct and indirect method can be used to obtain UCS in different situations. Direct method - uniaxial compressive test carried out in the laboratory, apart from being expensive and time consuming, is also destructive and not always practical especially in highly weathered rock samples. On the other hand, indirect method such as rebound hammer test using rebound Schmidt hammer, Brazilian test, point load and field estimation methods are less expensive, less time consuming and non-destructive. They are more useful in prediction of uniaxial compressive strength of intact rock and rock mass (Kahraman, 2001).

The rebound hammer or Schmidt hammer test is one of the mostly widely used nondestructive testing for uniaxial compressive strength estimation in mining. Literature related to prediction of uniaxial compressive strength using rebound hammer test is increasing since publication of Schmidt and Miller (Miller, 1965). Since that application of rebound hammer test using Schmidt hammer is increasingly used as alternative method of estimating UCS (Cobanoglu and Celik, 2008). Rebound number is an indicator of surface hardness of the sample. In civil and construction, non-destructive testing is widely employed for evaluating the quality of the concrete in the finished structures (Katz et al., 2000). In testing using rebound hammer, the hammer yields there bound number which gives an indication of the strength of the material being tested, for the rebound hammer test to be used; a typical regression model of UCS versus 
Prediction of Uniaxial Compressive Strength of Granite Rock Samples of Lugoba Quarry Using Rebound Hammer Test

RHN established using data obtained from field tests is normally used. Compressive strength of a rock material may be defined as the capacity of the rock to withstand loads tending to reduce size under compression (Deere and Miller, 1966), and is regarded as an index that can be used to test rock material for identification and classification (Shalabi et al., 2007).

Numerous studies have attempted to determine UCS and RHN values for granite. Available data indicate that granite is considered as one of the strong and competent rocks that break with one firm blow from hammer end of geological pick.
The UCS values ranges between 100 and $200 \mathrm{MPa}$ while RHN (N-type) varies between 50 and 60 (Goudie, 2006; Selby, 1993). Other studies such as Hoek and Brown (1980) and Hoek et al. (1992) considered $95 \mathrm{MPa}$ as minimum and 230 $\mathrm{MPa}$ as maximum while $160 \mathrm{MPa}$ is taken as an average. Other studies indicate that UCS values for granite rock lies between 100 and $250 \mathrm{MPa}$. Other UCS values for granites obtained from other studies may be summarized in Table 1. Similarly, studies on RHN values for granite from a few studies as summarized by Goudie (2006) and adopted in this study are given in Table 2.

Table 1: Some UCS values of Granite from Selected Studies

\begin{tabular}{|l|c|}
\hline Researcher & UCS value (MPa) \\
\hline Stillborg (1986) & $100-200$ \\
\hline Sundara (2009) & 115.6 \\
\hline Amadei (2000); Johnson and DeGraff (1988) & 181.7 \\
\hline ISRM (1978) & 136.32 \\
\hline Singh et al. (1983) & $119.78-136.32$ \\
\hline Quane and Russell (2003) & 138.59 \\
\hline
\end{tabular}

Table 2: Some RHN Values of Granite from Selected Studies

\begin{tabular}{|l|l|c|}
\hline Researcher & Granite Sampling Location & Mean value of RHN \\
\hline Ericson (2004) & Sierra Nevada, USA & $48-53$ \\
\hline Katz et al. $(2000)$ & Mt Scott granite, Oklahoma & 73.4 \\
\hline Ericson (2004) & Sweden & $55-56$ \\
\hline Brook et al. $(2004)$ & Scotland (Cairngorms granite) & 66.5 \\
\hline Day and Goudie (1977) & Shap, UK & $59.4-61.1$ \\
\hline Goudie (2006) & Namibia (Salem granite) & 59.4 \\
\hline Kahraman et al. (2004) & Turkey & $55.7-62.5$ \\
\hline
\end{tabular}

The most popular formula correlating UCS and RHN is that of Miller known as Miller's correlation formula $\operatorname{UCS}(\mathrm{MPa})=12.83 \mathrm{e}^{0.047 R H N}$. However, Wang et al. (2016) admits that the most evident attribute of empirical correlation is that the fitting relationship varies in different rock types and also exhibit variation for similar type of rock. The empirical relationships between UCS and RHN for granite and non-granite are in the forms of linear, exponential, power, quadratic and natural logarithm as shown in Table 3. The values of $\mathrm{R}$ squared in the table indicate very strong relationships between UCS and RHN. It is evident that the empirical correlations for the same rock type could be different for different samples coming from different locations. For example, the linear relationship models provided by Vasconselos et al. (2007) and Tugrul and Zarif (1999) for granite samples were different since the samples were from different locations. 
Thus, the main objective of this paper is to develop regression models of UCS vs. RHN based on data from Lugoba quarries that can be used to predict UCS at Lugoba quarries and other areas with similar rock characteristics. Such regression models have not been established and the existing ones cannot predict UCS of granite samples from Lugoba quarries with high accuracies.

Table 3: Various Forms of Empirical Relationships of UCS and RHN for Various Rocks

\begin{tabular}{|c|c|c|c|c|c|}
\hline No & Researcher & Empirical relations & $\mathbf{R}^{2}$ & Rock type & $\begin{array}{l}\text { Form of } \\
\text { relationship }\end{array}$ \\
\hline 1 & Shalabi et al. (2007) & UCS $=3.20 \mathrm{RHN}-46.59$ & 0.76 & $\begin{array}{l}\text { Shale, anhydrite, } \\
\text { dolomite }\end{array}$ & $\begin{array}{l}\text { Linear } \\
\text { equation }\end{array}$ \\
\hline 2 & Dincer et al. (2004) & UCS $=2.75 \mathrm{RHN}-36.83$ & 0.95 & $\begin{array}{l}\text { Andesite, basalts } \\
\text { and tuffs }\end{array}$ & $\begin{array}{l}\text { Linear } \\
\text { equation }\end{array}$ \\
\hline 3 & Saptonoet al. (2013) & UCS $=0.308 R H N^{1.327}$ & 0.9 & $\begin{array}{l}\text { Coal bearing } \\
\text { strata }\end{array}$ & $\begin{array}{l}\text { Power } \\
\text { function }\end{array}$ \\
\hline 4 & Nazir et al. (2013) & UCS $=12.83 e^{0.0487 R H N}$ & 0.91 & Limestone & $\begin{array}{l}\text { Exponential } \\
\text { equation }\end{array}$ \\
\hline 5 & Torobi et al. (2010) & UCS $=0.0465 R H N^{2}-0.175$ & 0.86 & $\begin{array}{l}\text { Roof rock of } \\
\text { coal mine }\end{array}$ & $\begin{array}{l}\text { Quadratic } \\
\text { equation }\end{array}$ \\
\hline 6 & Vasconselos et al., (2007) & UCS $=12.24 R H N-739.94$ & 0.83 & Granite & $\begin{array}{l}\text { Linear } \\
\text { equation }\end{array}$ \\
\hline 7 & Kats et al. (2000) & UCS $=0.00013 R H N^{2.09074}$ & 0.99 & Granite & $\begin{array}{l}\text { Power } \\
\text { function }\end{array}$ \\
\hline 8 & Tugrul and Zarif (1999) & UCS $=8.36 R H N-416.00$ & 0.87 & Granite & $\begin{array}{l}\text { Linear } \\
\text { equation }\end{array}$ \\
\hline 9 & Aydin and Basu (2005) & UCS $=1.45 e^{(0.07 R H N)}$ & 0.92 & Granite & $\begin{array}{l}\text { Exponential } \\
\text { equation }\end{array}$ \\
\hline 10 & Dearman and Irfan (1978) & UCS $=1.6 \times 10^{-4} R_{H N} N^{2,47}$ & 0.94 & Granite & $\begin{array}{l}\text { Power } \\
\text { function }\end{array}$ \\
\hline
\end{tabular}

\section{MATERIALS AND METHODS}

Determination of UCS for granite from Lugoba Quarry is based on the hypothesis that mathematical relations between RHN and UCS exist. Based on these mathematical relations RHN can be used to predict UCS.

\section{Model Formulation}

The models are in the form of linear, power, exponential, quadratic, and natural logarithm shown in equations (1) to (5).

\section{Linear model}

$\mathrm{UCS}=\mathrm{aRHN}+\mathrm{b}$

Power model

$\mathrm{UCS}=a R H N^{a}$

Exponential model

$\mathrm{UCS}=a R H N e^{b}$
Quadratic model

$\mathrm{UCS}=a R H N^{2}+b R H N+c$

Natural logarithmic model

$\mathrm{UCS}=\operatorname{aln} R H N(b)$

Where $\mathrm{a}, \mathrm{b}$ and $c$ are the regression coefficients to be estimated in the regression analysis and RHN- rebound hammer number.

\section{Laboratory Test for Determination of UCS}

Uniaxial compressive tests comprising a total number of 20 granite core samples (A-T) were carried out at the DIT Laboratory using procedures suggested by ISRM (1978) and Aydin (2008). The samples were collected from designated scanlines at Lugoba Quarry. The samples from drill cores were prepared by cutting them in such a way that the 


\section{Hammer Test}

lengths/diameter ratios were between the recommended ratios of 2 to 3 .

A cylindrical core sample was loaded axially with no support until failure occurred. The maximum value of the axial stress was recorded as load. The uniaxial compressive strength of a sample was then calculated using equation (6).

$$
\mathrm{UCS}=\frac{\operatorname{Load}(\mathrm{kN})}{\operatorname{Area}\left(\mathrm{m}^{2}\right)}
$$

\section{Laboratory Test for Determination of RHN}

The 20 core samples were used for rebound hammer test using Schmidt hammer (N-type). For each sample, 15 rebound tests were undertaken at different points on the core surface to have rebound numbers. The tests were performed vertically downward in relation to the surface position and in accordance with the ASTM (2001). The average rebound numbers were calculated for each sample and results entered in Table 5. Before the tests, the rebound hammer was calibrated using concrete cubes of $150 \mathrm{~mm}$ side length. The cube was fixed in a heavy compression machine with a force of 40 $\mathrm{kN}$. Rebound hammer was applied on two cube sides with 12 rebound numbers readings distributed on both sides. Cubes were then crushed to obtain compressive strength, the relationship between rebound number and compressive strength was established. The validation of the curve was carried out based on several concrete cube tests performed at the University of Dar es Salaam Structural Laboratory. Validation of results was consistence and appropriate for application of the rebound hammer in this study.

\section{RESULTS AND DISCUSSION}

The laboratory results for UCS and RHN are given in Table 4 and 5, respectively and a summary given in Table 6 . As seen in Table 6, the mean value of UCS for granite samples obtained from laboratory test was $119.89 \mathrm{MPa}$. This is comparable with the values $(95-250 \mathrm{MPa})$ of other granite from other parts of the world. However, the mean value of RHN was 47.16 which was considered slightly lower than the values $(50-60)$ of other granite from other parts of the world.

\section{Model Validation}

Existing models were first validated using RHN and UCS data obtained from laboratory before qualifying them for application at Lugoba. Four models namely Vasconselos et al. (2007); Kats et al. (2000); Tugrul and Zarif (1999) and Aydin and Basu (2005) were picked from Table 3 for this purpose. RHN data were plugged in each model and errors calculated based on equation (7). Table 7 provides validation results.

$$
\text { Error in UCS }=\frac{(\mathrm{Lab} \text { UCS-Model UCS }) * 100 \%}{\text { Lab UCS }}
$$

It could be observed that the existing models can predict UCS for Lugoba granite samples with a minimum mean error between $\pm 43 \%$ for Aydin and Basu (2005) and the maximum error of $\pm 238 \%$ for Vasconseloe et al. (2007). These errors were considered too high for the models to be used at Lugoba quarries. However, they provide an avenue for the establishment of new models at Lugoba quarries.

\section{Regression Analysis}

In the regression analysis using SPSS software, UCS was selected as dependent variable while RHN was an independent variable. A curve estimation fit was selected since it allows fitting of one form of the five models at a time. Therefore, linear, logarithmic, quadratic, power, and exponential were fitted to generate mathematical models. 
Discussion of Regression Analysis and Models

Model summary for the 5 regression analyses of UCS versus RHN as obtained from SPSS outputs were reported in Table 8 and provides the basis for discussion. The values of $R^{2}$ for the 5 models were found to be between 0.93 and 0.95 indicating that RHN accounted between $93 \%$ and $95 \%$ of the total variation of the UCS. This implies that RHN significantly predicted UCS and the relationships were very strong with values of $F$ very much greater than 1 and $p<0.01$. The obtained values of $R^{2}$ are comparable with those obtained by other researchers shown in Table 3.

Regression coefficients of the five models are the unstandardized coefficients B of the RHN and constants B. Quadratic model was the only model with coefficient c which however, was not found significant and therefore was not reported in the Table. The table, further, shows: In Quadratic Model, RHN was not significantly predicting UCS, $\mathrm{t}$ (19) = $1.270, p>0.05$ and also constant (19) $=$ $1.279, p>0.05$. In Power Model, RHN was significantly predicting UCS, t (19) = 15.908, $\mathrm{p}<0.01$, however, constant was not, $\mathrm{t}(19)=-1.967, p>0.05$.

\section{Established models:}

$>\quad$ Linear Model: RHN was significantly predicting UCS, t $(19)=16.609, \mathrm{p}<.01$ and also the constant, $\mathrm{t}(19)=-8.639, \mathrm{p}<.01$.

UCS $=5.301 \mathrm{~N}-130.00$

$>\quad$ Logarithmic Model: RHN was significantly predicting UCS, t (19) $=16.818, \mathrm{p}<.01$ and also constant, $\mathrm{t}(1)=-14.726, \mathrm{p}<.01$

$\mathrm{UCS}=250.21 \ln N-844.15$.

$>\quad$ Exponential Model: RHN was significantly predicting UCS, t $(19)=15.38, \mathrm{p}<.01$ and also constant, $\mathrm{t}(19)=-7.456, \mathrm{p}<.01$

$\mathrm{UCS}=14.70 \mathrm{e}^{0.044 \mathrm{~N}}$

Table 4: UCS Test Results for Granite Rock Samples

\begin{tabular}{|c|c|c|c|c|c|}
\hline Sample ID & Length $(\mathrm{m})$ & Diameter $(\mathrm{m})$ & Area $\left(\mathrm{m}^{2}\right)$ & Load $(\mathrm{kN})$ & UCS $(\mathrm{MPa})$ \\
\hline A & 0.092 & 0.0445 & 0.00156 & 181.33 & 116.24 \\
\hline B & 0.094 & 0.0445 & 0.00156 & 139.00 & 89.10 \\
\hline C & 0.092 & 0.0445 & 0.00156 & 103.90 & 66.60 \\
\hline D & 0.093 & 0.0445 & 0.00156 & 170.00 & 108.97 \\
\hline E & 0.092 & 0.0445 & 0.00156 & 142.09 & 91.08 \\
\hline F & 0.092 & 0.0445 & 0.00156 & 132.32 & 84.82 \\
\hline G & 0.093 & 0.0445 & 0.00156 & 109.65 & 70.29 \\
\hline H & 0.094 & 0.0445 & 0.00156 & 149.41 & 95.78 \\
\hline I & 0.093 & 0.0445 & 0.00156 & 190.08 & 121.85 \\
\hline J & 0.092 & 0.0445 & 0.00156 & 100.07 & 64.15 \\
\hline K & 0.093 & 0.0445 & 0.00156 & 190.78 & 122.29 \\
\hline L & 0.094 & 0.0445 & 0.00156 & 123.09 & 78.90 \\
\hline M & 0.092 & 0.0445 & 0.00156 & 183.32 & 117.51 \\
\hline N & 0.092 & 0.0445 & 0.00156 & 135.89 & 87.11 \\
\hline O & 0.093 & 0.0445 & 0.00156 & 187.62 & 120.27 \\
\hline P & 0.092 & 0.0445 & 0.00156 & 194.07 & 124.40 \\
\hline Q & 0.094 & 0.0445 & 0.00156 & 164.79 & 105.63 \\
\hline R & 0.094 & 0.0445 & 0.00156 & 121.10 & 77.63 \\
\hline S & 0.093 & 0.0445 & 0.00156 & 101.76 & 65.23 \\
\hline T & 0.092 & 0.0445 & 0.00156 & 130.34 & 83.55 \\
\hline
\end{tabular}


Table 5: RHN Test Results for Granite Samples

\begin{tabular}{|c|c|c|c|c|c|c|c|c|c|c|c|c|c|c|c|c|}
\hline $\begin{array}{c}\text { Sample } \\
\text { ID }\end{array}$ & $\mathbf{1}$ & $\mathbf{2}$ & $\mathbf{3}$ & $\mathbf{4}$ & $\mathbf{5}$ & $\mathbf{6}$ & $\mathbf{7}$ & $\mathbf{8}$ & $\mathbf{9}$ & $\mathbf{1 0}$ & $\mathbf{1 1}$ & $\mathbf{1 2}$ & $\mathbf{1 3}$ & $\mathbf{1 4}$ & $\mathbf{1 5}$ & $\begin{array}{c}\text { Average } \\
\text { Rebound } \\
\text { Number }\end{array}$ \\
\hline $\mathrm{A}$ & 49 & 34 & 45 & 50 & 37 & 40 & 48 & 46 & 40 & 54 & 57 & 46 & 48 & 46 & 53 & $\mathbf{4 6 . 0}$ \\
\hline $\mathrm{B}$ & 51 & 58 & 55 & 32 & 49 & 49 & 40 & 34 & 50 & 56 & 48 & 44 & 47 & 53 & 50 & $\mathbf{4 6 . 5}$ \\
\hline $\mathrm{C}$ & 48 & 41 & 45 & 44 & 46 & 44 & 45 & 47 & 44 & 38 & 46 & 45 & 49 & 44 & 48 & $\mathbf{4 4 . 9}$ \\
\hline $\mathrm{D}$ & 45 & 40 & 45 & 49 & 49 & 50 & 51 & 53 & 53 & 50 & 48 & 49 & 47 & 47 & 47 & $\mathbf{4 5 . 0}$ \\
\hline $\mathrm{E}$ & 51 & 49 & 50 & 45 & 43 & 51 & 50 & 48 & 49 & 40 & 40 & 43 & 43 & 42 & 49 & $\mathbf{4 6 . 2}$ \\
\hline $\mathrm{F}$ & 42 & 50 & 52 & 44 & 50 & 43 & 49 & 50 & 49 & 38 & 49 & 47 & 45 & 44 & 43 & $\mathbf{4 6 . 0}$ \\
\hline $\mathrm{G}$ & 48 & 42 & 44 & 42 & 46 & 50 & 50 & 40 & 43 & 44 & 50 & 56 & 50 & 49 & 40 & $\mathbf{4 6 . 9}$ \\
\hline $\mathrm{H}$ & 48 & 40 & 50 & 47 & 50 & 47 & 49 & 42 & 47 & 50 & 50 & 50 & 51 & 50 & 54 & $\mathbf{4 5 . 5}$ \\
\hline $\mathrm{I}$ & 43 & 48 & 49 & 49 & 46 & 47 & 46 & 50 & 44 & 45 & 42 & 49 & 48 & 40 & 49 & $\mathbf{4 6 . 0}$ \\
\hline $\mathrm{J}$ & 45 & 47 & 51 & 52 & 49 & 48 & 47 & 50 & 52 & 52 & 54 & 47 & 50 & 50 & 49 & $\mathbf{4 9 . 5}$ \\
\hline $\mathrm{K}$ & 50 & 46 & 48 & 47 & 51 & 49 & 40 & 39 & 42 & 42 & 48 & 47 & 50 & 49 & 47 & $\mathbf{4 7 . 0}$ \\
\hline $\mathrm{L}$ & 52 & 50 & 49 & 40 & 45 & 44 & 43 & 45 & 49 & 44 & 50 & 50 & 52 & 54 & 49 & $\mathbf{4 7 . 6}$ \\
\hline $\mathrm{M}$ & 47 & 47 & 43 & 42 & 50 & 44 & 45 & 50 & 51 & 48 & 49 & 47 & 42 & 44 & 43 & $\mathbf{4 6 . 0}$ \\
\hline $\mathrm{N}$ & 54 & 50 & 48 & 50 & 52 & 50 & 55 & 56 & 49 & 47 & 42 & 40 & 40 & 41 & 42 & $\mathbf{4 7 . 7}$ \\
\hline $\mathrm{O}$ & 50 & 52 & 50 & 49 & 47 & 42 & 42 & 48 & 56 & 44 & 48 & 48 & 51 & 51 & 53 & $\mathbf{4 8 . 8}$ \\
\hline $\mathrm{P}$ & 53 & 54 & 51 & 51 & 49 & 44 & 58 & 48 & 50 & 52 & 50 & 46 & 47 & 42 & 42 & $\mathbf{4 6 . 0}$ \\
\hline $\mathrm{Q}$ & 46 & 51 & 52 & 50 & 46 & 51 & 53 & 49 & 51 & 42 & 52 & 56 & 43 & 42 & 45 & $\mathbf{4 8 . 6}$ \\
\hline $\mathrm{R}$ & 43 & 41 & 50 & 48 & 50 & 52 & 50 & 56 & 51 & 49 & 54 & 56 & 56 & 42 & 42 & $\mathbf{4 9 . 0}$ \\
\hline $\mathrm{S}$ & 49 & 47 & 49 & 47 & 53 & 47 & 47 & 48 & 52 & 50 & 51 & 45 & 40 & 50 & 51 & $\mathbf{4 8 . 4}$ \\
\hline $\mathrm{T}$ & 42 & 50 & 48 & 44 & 42 & 43 & 48 & 48 & 50 & 58 & 44 & 43 & 45 & 50 & 45 & $\mathbf{4 6 . 0}$ \\
\hline
\end{tabular}

Table 6: Summary of Descriptive Statistics for UCS and RHN for 20 Observations

\begin{tabular}{|l|c|c|c|c|c|c|}
\hline & Mean & Median & Mode & Std. deviation & Minimum & Maximum \\
\hline UCS (MPa) & 119.89 & 120.51 & 130.00 & 7.74 & 105.00 & 132.50 \\
\hline RHN & 47.16 & 47.00 & 46.00 & 1.41 & 44.90 & 49.50 \\
\hline
\end{tabular}

Although the generated models were linear, logarithmic and exponential in nature similar to other studies, the obtained coefficients were different. Thus, the models can only be applied at Lugoba granite quarries or in other granite quarries with similar characteristics.

\section{Graphical Presentation of the Models}

The three generated mathematical models can be graphically superimposed and presented as shown in Figure 2. Validation of the Established Models
The established models were validated based on equation (7) and the results indicated that the models can predict UCS with a mean error of less than \pm 10 for the logarithmic and exponential models. However, the mean error for the linear model was found to be greater than $\pm 10 \%$. Based on these results, logarithmic and exponential models were recommended for use at Lugoba quarries. 
Moses Kongola and Karim R. Baruti

Table 7: Validation Results for the Existing Models based on Laboratory Results of Lugoba Granite Samples

\begin{tabular}{|c|c|c|c|c|c|c|c|c|c|c|}
\hline \multicolumn{2}{|c|}{ Lab Results } & \multirow[b]{2}{*}{ UCS } & \multicolumn{2}{|c|}{ Vasconselos et al (2007) } & \multicolumn{2}{|c|}{ Kats et (2000) } & \multicolumn{4}{|c|}{ Tugrul and Zarif (1999) Aydin and Basu (200 } \\
\hline ID & RHN & & UCS & Error & UCS & Error & UCS & Error & UCS & Error \\
\hline A & 46.00 & 116.00 & $(176.90)$ & 252.50 & 17.91 & 84.56 & $(31.44)$ & 127.10 & 25.03 & 45.59 \\
\hline B & 46.50 & 125.00 & $(170.78)$ & 236.62 & 18.52 & 85.19 & $(27.26)$ & 121.81 & 25.92 & 44.26 \\
\hline $\mathrm{C}$ & 44.90 & 130.00 & $(190.36)$ & 246.43 & 16.62 & 87.22 & $(40.64)$ & 131.26 & 23.17 & 48.39 \\
\hline D & 45.00 & 121.00 & (189.14) & 256.31 & 16.73 & 86.17 & $(39.80)$ & 132.89 & 23.34 & 48.14 \\
\hline$E$ & 46.20 & 128.00 & (174.45) & 236.29 & 18.15 & 85.82 & (29.77) & 123.26 & 25.38 & 45.06 \\
\hline $\mathrm{F}$ & 46.00 & 123.00 & (176.90) & 243.82 & 17.91 & 85.44 & $(31.44)$ & 125.56 & 25.03 & 45.59 \\
\hline $\mathrm{G}$ & 46.90 & 120.02 & (165.88) & 238.21 & 19.02 & 84.16 & $(23.92)$ & 119.93 & 26.66 & 43.16 \\
\hline $\mathrm{H}$ & 45.50 & 123.48 & (183.02) & 248.22 & 17.32 & 85.98 & $(35.62)$ & 128.85 & 24.17 & 46.88 \\
\hline I & 46.00 & 120.00 & (176.90) & 247.42 & 17.91 & 85.08 & $(31.44)$ & 126.20 & 25.03 & 45.59 \\
\hline J & 49.50 & 132.50 & (134.06) & 201.18 & 22.47 & 83.04 & $(2.18)$ & 101.65 & 31.98 & 35.40 \\
\hline $\mathrm{K}$ & 47.00 & 109.99 & (164.66) & 249.70 & 19.14 & 82.60 & (23.08) & 120.98 & 26.84 & 42.89 \\
\hline $\mathrm{L}$ & 47.60 & 130.00 & (157.32) & 221.01 & 19.91 & 84.69 & $(18.06)$ & 113.90 & 27.99 & 41.19 \\
\hline $\mathrm{M}$ & 46.00 & 123.45 & (176.90) & 243.30 & 17.91 & 85.49 & (31.44) & 125.47 & 25.03 & 45.59 \\
\hline $\mathrm{N}$ & 47.70 & 111.00 & (156.09) & 240.62 & 20.04 & 81.95 & $(17.23)$ & 115.52 & 28.19 & 40.90 \\
\hline 0 & 48.80 & 117.90 & (142.63) & 220.97 & 21.50 & 81.77 & $(8.03)$ & 106.81 & 30.45 & 37.61 \\
\hline$P$ & 46.00 & 110.00 & (176.90) & 260.82 & 17.91 & 83.72 & (31.44) & 128.58 & 25.03 & 45.59 \\
\hline$Q$ & 48.60 & 112.00 & (145.08) & 229.53 & 21.23 & 81.05 & $(9.70)$ & 108.66 & 30.02 & 38.22 \\
\hline $\mathrm{R}$ & 49.00 & 113.89 & (140.18) & 223.08 & 21.77 & 80.88 & $(6.36)$ & 105.58 & 30.88 & 36.99 \\
\hline$S$ & 48.40 & 105.00 & (147.52) & 240.50 & 20.96 & 80.04 & $(11.38)$ & 110.83 & 29.61 & 38.83 \\
\hline$T$ & 46.00 & 125.66 & (176.90) & 240.78 & 17.91 & 85.75 & (31.44) & 125.02 & 25.03 & 45.59 \\
\hline
\end{tabular}

Table 8: Model Summary and Coefficients

\begin{tabular}{|c|c|c|c|c|c|}
\hline & \multicolumn{5}{|c|}{ Model } \\
\hline & Linear & Logarithmic & Quadratic & Power & Exponential \\
\hline \multicolumn{6}{|l|}{ Model summary } \\
\hline$R^{2}$ & 0.94 & 0.94 & 0.94 & 0.93 & 0.93 \\
\hline df & $(1,19)$ & $(1,19)$ & $(2,19)$ & $(1,19)$ & $(1,19)$ \\
\hline $\mathrm{F}$ & 275.87 & 282.86 & 139.29 & 253.07 & 244.55 \\
\hline Sig. & 0.00 & 0.00 & 0.00 & 0.00 & 0.00 \\
\hline \multicolumn{6}{|l|}{ Schmidt Number RHN } \\
\hline Unstandardized Coefficient B & 5.30 & 250.21 & 30.67 & 2.10 & 0.04 \\
\hline Unstandardized Coefficient Std error & 0.32 & 14.88 & 24.15 & .132 & 0.003 \\
\hline Standardized Coefficient beta & 0.97 & 0.97 & 5.61 & 0.97 & 0.97 \\
\hline t- value & 16.61 & 16.82 & 1.27 & 15.91 & 15.64 \\
\hline Sig. & 0.00 & 0.00 & 0.22 & .00 & .00 \\
\hline \multicolumn{6}{|l|}{ (Constant) } \\
\hline Unstandardized Coefficient B & -130.08 & -844.16 & -728.63 & 0.04 & 14.71 \\
\hline Unstandardized Coefficient Std error & 15.06 & 57.32 & 569.43 & 0.02 & 1.97 \\
\hline \multicolumn{6}{|l|}{ Standardized Coefficient beta } \\
\hline t- value & -8.64 & -14.73 & 1.28 & 1.97 & 7.46 \\
\hline Sig. & 0.00 & 0.00 & 0.22 & 0.07 & 0.00 \\
\hline
\end{tabular}


Prediction of Uniaxial Compressive Strength of Granite Rock Samples of Lugoba Quarry Using Rebound Hammer Test

UCS

(Mpa)

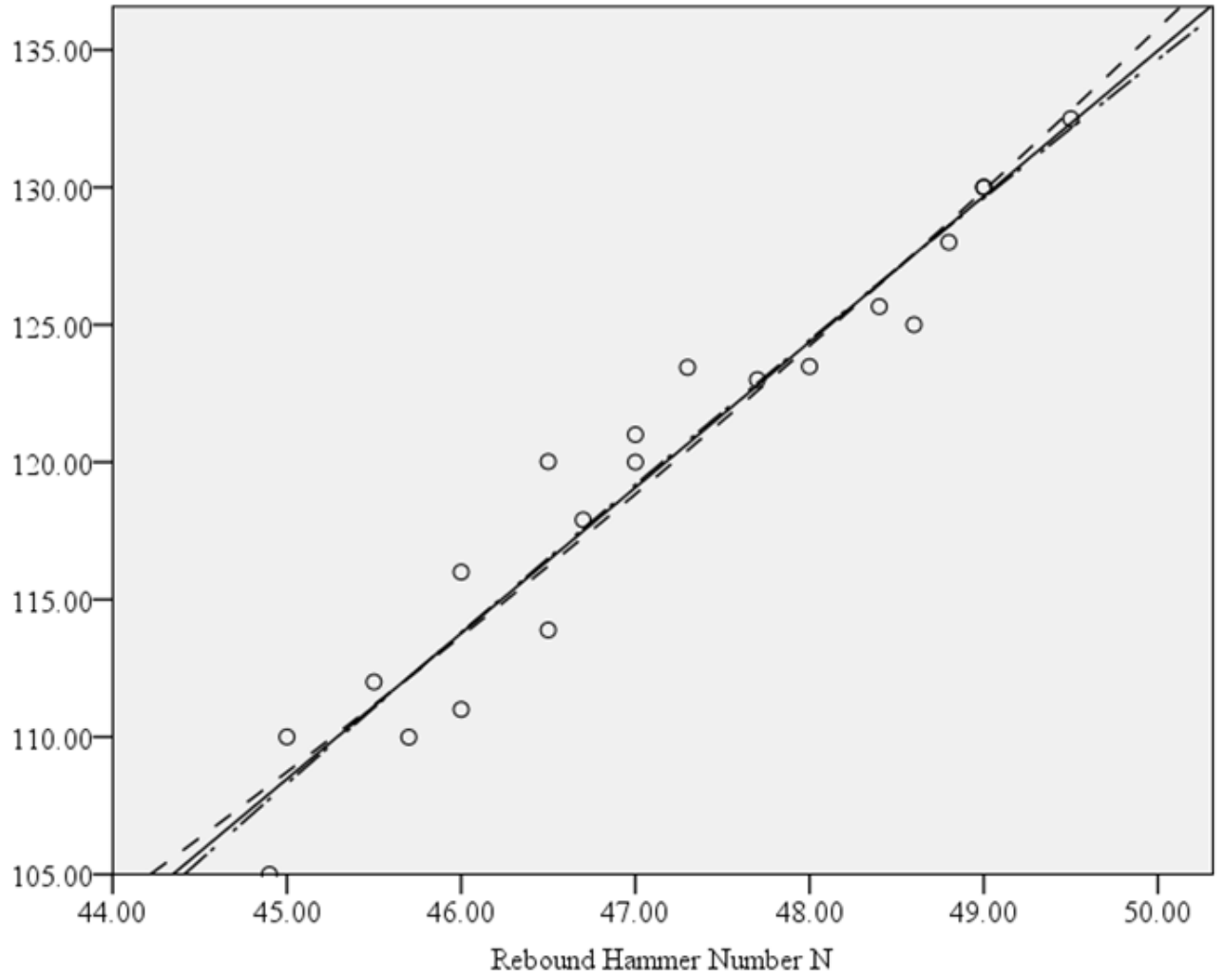

O Observed

- Linear

-. Logarithmic

- Exponential

Figure 2: Superimposed Models of Linear, Logarithmic and Exponential Graphs

Table 9: Errors for the Linear, logarithmic and Exponential Models

\begin{tabular}{|l|r|r|r|r|r|r|r|r|}
\hline \multicolumn{2}{|l|}{ Lab Results } & \multicolumn{1}{l|}{ Linear Model } & \multicolumn{2}{l|}{ Logarithmic Model } & \multicolumn{2}{l|}{ Exponential Model } \\
\hline ID & RHN & UCS & \multicolumn{1}{l|}{ UCS } & \multicolumn{1}{l|}{ Error } & \multicolumn{1}{l|}{ UCS } & \multicolumn{1}{l|}{ Error } & \multicolumn{1}{l|}{ UCS } & \multicolumn{1}{c|}{ Error } \\
\hline A & 46.00 & 116.00 & 113.85 & 17.86 & 113.81 & 1.88 & 111.26 & $(4.09)$ \\
\hline B & 46.50 & 125.00 & 116.50 & 31.80 & 116.52 & 6.78 & 113.73 & $(9.01)$ \\
\hline C & 44.90 & 130.00 & 108.01 & 46.91 & 107.76 & 17.11 & 106.00 & $(18.46)$ \\
\hline D & 45.00 & 121.00 & 108.55 & 31.29 & 108.32 & 10.48 & 106.47 & $(12.01)$ \\
\hline E & 46.20 & 128.00 & 114.91 & 38.23 & 114.90 & 10.23 & 112.24 & $(12.31)$ \\
\hline F & 46.00 & 123.00 & 113.85 & 30.44 & 113.81 & 7.47 & 111.26 & $(9.55)$ \\
\hline G & 46.90 & 120.02 & 118.62 & 21.19 & 118.66 & 1.13 & 115.75 & $(3.56)$ \\
\hline H & 45.50 & 123.48 & 111.20 & 33.43 & 111.08 & 10.04 & 108.84 & $(11.86)$ \\
\hline I & 46.00 & 120.00 & 113.85 & 25.13 & 113.81 & 5.15 & 111.26 & $(7.28)$ \\
\hline J & 49.50 & 132.50 & 132.40 & 32.58 & 132.16 & 0.25 & 129.78 & $(2.05)$ \\
\hline K & 47.00 & 109.99 & 119.15 & 1.66 & 119.20 & $(8.37)$ & 116.26 & 5.70 \\
\hline L & 47.60 & 130.00 & 122.33 & 35.90 & 122.37 & 5.87 & 119.37 & $(8.17)$ \\
\hline M & 46.00 & 123.45 & 113.85 & 31.23 & 113.81 & 7.81 & 111.26 & $(9.88)$ \\
\hline N & 47.70 & 111.00 & 122.86 & 0.32 & 122.89 & $(10.72)$ & 119.90 & 8.02 \\
\hline O & 48.80 & 117.90 & 128.69 & 8.75 & 128.60 & $(9.07)$ & 125.85 & 6.74 \\
\hline P & 46.00 & 110.00 & 113.85 & 6.50 & 113.81 & $(3.47)$ & 111.26 & 1.14 \\
\hline Q & 48.60 & 112.00 & 127.63 & $(1.95)$ & 127.57 & $(13.90)$ & 124.74 & 11.38 \\
\hline R & 49.00 & 113.89 & 129.75 & $(0.03)$ & 129.62 & $(13.81)$ & 126.96 & 11.47 \\
\hline S & 48.40 & 105.00 & 126.57 & $(15.54)$ & 126.54 & $(20.51)$ & 123.65 & 17.76 \\
\hline T & 46.00 & 125.66 & 113.85 & 35.06 & 113.81 & 9.43 & 111.26 & $(11.46)$ \\
\hline
\end{tabular}




\section{CONCLUSIONS AND RECOMMENDATIONS}

In view of the literature review, laboratory results and the generated models, we can conclude that:

- RHN has been extensively used to predict a crucial UCS parameter because of its advantages over the direct method of using UCS machine and for similar reason it can be used to predict UCS of granite at Lugoba Quarry;

- The mean value of UCS of granite samples from Lugoba quarry obtained in the UCS test carried out at DIT Laboratory based on the 20 samples were $119.89 \mathrm{MPa}$ and corresponding RHN was 47.16. These values are comparable with the values $(95-250$ $\mathrm{MPa})$ and $(50-60)$ of other granite from other parts of the world though the mean value of RHN was considered slightly lower;

- The existing models of UCS selected in this study can predict UCS of Lugoba granite with the mean errors ranging between $\pm 43 \%$ and $\pm 238 \%$. The errors were considered too high for the models to be used at Lugoba.

- The five new models were established and values of $R^{2}$ for the models were found to be between 0.93 and 0.95 which are comparable with other studies. RHN accounted between 93\% and $95 \%$ of the total variation of the UCS and the relationships are very strong;

- Three models - linear, logarithmic and exponential were found to be appropriate for predicting UCS at Lugoba Quarry. However, validation results indicated that only Logarithmic and exponential models can predict UCS of Lugoba granite with a mean error less than $\pm 10 \%$ and therefore were recommended for further use at Lugoba granite quarry.

Rebound hammer number obtained from Rebound Schmidt hammer can be used to predict UCS at Lugoba quarry using established regression models logarithmic, and exponential.

\section{ACKNOWLEDGEMENTS}

The authors are very thankful to Ms Daria Munish for the invaluable inputs and execution of all the laboratory works related to this study which was performed at Dar es Salaam Institute of Technology.

\section{REFERENCES}

Amadei B. (2000). CVEN 5768- Lecture notes 8 in Rock Mechanics, University of Colorado.

American Society for Testing Materials (ASTM) (2001). Standard Test Method for Determination of Rock Hardness by Rebound Hammer Method, ASTM Stand 04.09. (D 5873-00).

Aydin A. and Basu A. (2005). The Schmidt Hammer in Rock Material Characterization. Engineering Geology, 81(1): 1-14. DOI: 10.1016/j.enggeo.2005.06.006

Aydin A. (2008). International Society of Rock Mechanics (ISRM) Suggested Method for Determination of the Schmidt Hammer Rebound Hardness: Revised Version, International Journal of Rock Mechanics and Mining Sciences, 46(3): 627-634.

https://doi.org/10.1016/j.ijrmms.2008.0 $\underline{1.020}$

Bewick R.P., Amann F., Kaiser P.K. and Martin C.D. (2015). Interpretation of UCS Test Results for Engineering Design, ISRM Congress 2015 Proceedings - International Symposium on Rock Mechanics, May 10-13, Montreal, Canada

Brook M.S., Kirkbride M.P. and Brock B.W. (2004). Rock Strength and Development of Glacial Valley Morphology in the Scottish Highlands and Northwest Iceland, Geografiska Annaler: Series A, Physical Geography, 86(3): 225-34. 
Prediction of Uniaxial Compressive Strength of Granite Rock Samples of Lugoba Quarry Using Rebound

Hammer Test

https://doi.org/10.1111/j.04353676.2004.00227.x

Çobanoğlu I. and Çelik S.B. (2008). Estimation of Uniaxial Compressive Strength from Point Load Strength, Schmidt Hardness and P-wave Velocity. Bulletin of Engineering Geology and the Environment, 67(4): 491-498. DOI: $10.1007 / \mathrm{s} 10064-008-$ 0158-x

Day M.J. and Goudie A.S. (1977). Field Assessment of Rock Hardness Using the Schmidt Test Hammer, BGRG Technical Bulletin 18: 19-29.

Dearman W.R. and Irfan T.Y. (1978). Assessment of the Degree of Weathering in Granite using Petrographic and Physical Index Tests. In Proceeding of the International Symposium on Deterioration and Protection of Stone Monuments, Paris, UNESCO, 1-35.

Deere D.U. and Miller R.P. (1966). Engineering Classification of Index Properties of Intact Rock, Technical Repair. Air Force Weapons Laboratory, New Mexico, AFNL-TR, 65-116.

Dinçer, I., Acar, A., Çobanoğlu and Uras Y. (2004). Correlation between Schmidt Hardness, Uniaxial Compressive Strength and Young's Modulus for Andesites, Basalts and Tuffs. Bulletin of Engineering Geology and the Environment, 63: 141-48. https://doi.org/10.1007/s10064-004-0230-0

Ericson K. (2004). Geomorphological Surface of Different Age and Origin in Granite Landscapes: An Evaluation of the Schmidt Test Hammer. Earth Surface Processes and Landforms, 29(4): $\quad$ 495-509. https://doi.org/10.1002/esp.1048

Goudie A.S. (2006). The Schmidt Hammer in Geomorphological Research, Progress in Physical Geography, 30(6): 703-718.

DOI:10.1177/0309133306071954

Hack H.R.G.K. (1998). Slope Stability Probability Classification (SSPC). $2^{\text {nd }}$ edition, Publication ITC No. 43, Enschede, The Netherlands.

Hoek E. and Brown E.T. (1980). Empirical Strength Criterion for Rock Masses, American Society of Civil Engineers (ASCE), Journal of Geotechnical Engineering, 106: 1013-1035.

Hoek E., Wood D. and Shah S. (1992). A Modified Hoek-Brown Criterion for Jointed Rock Masses in Hudson, J.A. (ed) Proceedings of the Rock Mechanics Symposium. International Society of Rock Mechanics" Eurock 92, British Geotechnical Society, London, 209-214.

International Society of Rock Mechanics (ISRM) (1978). Rock Characterization Testing and Monitoring, ISRM Suggested Methods, Commission on Testing Methods. Oxford, Pergamon Press Ltd.

Johnson R.B. and DeGraff J.V. (1988). Principles of Engineering Geology, Wiley \& Sons, New York.

Kahraman S. (2001). Evaluation of Simple Methods for Assessing the Uniaxial Compressive Strength of Rock, International Journal of Rock Mechanics and Mining Science, 38(7): 981-994. DOI:10.1016/S13651609(01)00039-9

Kahraman S., Fener M. and Gunaydin O. (2004). Predicting the Sawability of Carbonate Rocks Using Multiple Curvilinear Regression Analysis. International Journal of Rock Mechanics and Mining Sciences, 41(7): 1123-1131.

DOI:10.1016/j.ijrmms.2004.04.009

Katz O., Reches Z. and Roegiers J.C. (2000). Evaluation of Mechanical Rock Properties Using a Schmidt Hammer. International Journal of Rock Mechanics and Mining Sciences, 37(4): 723-728. DOI: $10.1016 / \mathrm{S} 1365-$ 1609(00)00004-6

Kikwasi G.J. and Escalante C. (2020). The Construction Sector in Tanzania, Mining for Change: Natural Resources and Industry in Africa, Oxford Scholarship Online. DOI:10.1093/oso/9780198851172.003. 0012 
Laubscher D.H. (1990). A Geomechanics Classification System for Rating of Rockmass in Mine Design. Journal of South African Institute of Mining and Metallurgy, 90(10):257 - 273.

Miller R.P. (1965). Engineering Classification and Index Properties for Intact Rock, PhD Thesis, University of Illinois.

Nazir R., Momeni E., Armaghani D.J. and Amin M.M. (2013). Prediction of Unconfined Compressive Strength of Limestone Rock Samples using L-Type Schmidt Hammer, Electronic Journal of Geotechnical Engineering, 18:17671775. Corpus ID: 132093728

Quane S.L and Russell J.K. (2003). Rock Strength as a Metric Welding Intensity in Pyroclastic Deposits, European Journal of Mineralogy, 15(5): 855-864. DOI: $10.1127 / 0935-1221 / 2003 / 0015-$ $\underline{0855}$

Saptono S., Kramadibrata S., Sulistianto B. (2013). Using the Schmidt Hammer on Rock Mass Characteristic in Sedimentary Rock at Tutapan Coal Mine, Procedia Earth and Planetary Science, 6: 390-395. https://doi.org/10.1016/j.proeps.2013.01 .051

Selby M.J. (1993). A Rock Mass Strength Classification for Geomorphic Purpose: with Test from Antarctica and New Zealand. Zeitschrift fur Geomorphologies, 24: 31-51. Corpus ID: 210315687

Shalabi F.I., Cording E.J., Al-Hattamleh O.H. (2007). Estimation of Rock Engineering Properties Using Hardness Tests, Engineering Geology, 90(3-4): 138-147.

https://doi.org/10.1016/j.enggeo.2006.1 2.006

Singh R.N., Hassani F.P. and Elkington P.A.S. (1983). The Application of Strength and Deformation Index Testing to Stability Assessment of Coal Measures Excavations. Proceedings of the $24^{\text {th }}$ US Symposium on Rock Mechanics, Texas A\&M University, 599-609.
Stillborg B. (1986). Professional Users Handbook for Rock Bolting. Germany Transtech Publication.

Sundara P. (2009). Correlation between Uniaxial Compressive Strength and Point Load Index Strength, Master of Engineering (Civil-Geotechnics), Faculty of Engineering. Universiti Teknologi Malaysia.

Torobi S.R., Ataei M. and Javanshir (2010). Application of Schmidt Rebound Number for Estimating Rock Strength under Specific Geological Conditions, Journal of Mining and Environment, $1(2)$ : $1-8$. 10.22044/JME.2011.9

Tuğrul A. and Zarif I.H. (1999). Correlation of mineralogical and textural characteristics with engineering properties of selected granitic rocks from Turkey, Engineering Geology, 51(4): 303-317. https://doi.org/10.1016/S00137952(98)00071-4

Twiga Cement Company (2014). Twiga Aggregates Quality Control, Tanzania Portland Cement Company Limited, Dar es Salaam.

United Nations (2019). Dar es Salaam, Tanzania Metro Area Population 19502020, World Population Prospects. Available online at https://www.macrotrends.net/cities/228 94/dar-es-salaam/population

Vasconcelos G., Lourenco P.P., Alves C.S.A. and Pamplona J. (2007). Prediction of the Mechanical Properties of Granites by Ultrasonic Pulse Velocity and Schmidt Hammer Hardness, the $10^{\text {th }}$ American Masonry Conference, St Louis, Missouri, USA.

Wang H., Lin H. and Cao P. (2016). Correlation of UCS Rating with Schmidt Hammer Surface Hardness for Rock Mass Classification, Rock Mechanics and Rock Engineering, 50: 195-203.

https://doi.org/10.1007/s00603-0161044-7 